\title{
TRANSNATIONALISING JAMAAH ISLAMIYYAH
}

\section{Syaifudin Zuhri}

The Sociology of Religion Department, State Islamic University (UIN)

Sunan Kalijaga Yogyakarta, Indonesia

\begin{abstract}
This article attempts to historically analyse the emergence of transnational jihadist movements in Indonesia, focusing on Jamaah Islamiyyah (II), which is allegedly responsible for a number of terror attacks in South East Asia. The article discusses the historical background of the emergence of Jamaah Islamiyyah and its current development. It is argued that the Afghan battle-field was an important event and locus for Indonesian jibadits groups to exercise their military capabilities, establish secure bases and subsequently pave the emergence of the transnational jibadist. Through informal networks and joint operations, Jamaah Islamiyyah has become the bub for jihadist movements in Southeast Asia. It was the political opportunity of the reformation which gave way to the public appearance of Jamaah Islamiyyah as the MMI demonstrated, but it also brought the consequence of a split among JI activists. The split reappears when the MMI was becoming involved in politics, and the resignation of Ba'asyir from the top position of the MMI in 2008 exemplifies the turning point to the ideological foundation of JI as the Pedoman Umum Perjuangan Jamaah Islamiyyah (PUPJI) prescribed.
\end{abstract}

Keywords: Darul Islam, Abu Bakar Ba'asyir, Jamaah Islamiyyah

\section{A. Introduction}

On 18 February 2002, the former Prime Minister of Singapore, Lee Kwan Yew, called Indonesia "a nest of terrorists" and accused Abu Bakar Ba'asyir of being the leader of the most dangerous terrorist 
organisation in Southeast Asia, Jamaah Islamiyyah. ${ }^{1}$ His words led to many responses from the Indonesian government and Indonesian Islamic organisations. The Indonesian Foreign Minister condemned Yew's statement as provocative and an accusation without any evidence, later sending a diplomatic note to the former Minister of Singapore. A number of Indonesian Islamic organisations took to the streets, demonstrating in front of the Embassy of Singapore and accusing Mr. Yew of interfering in Indonesian politics. ${ }^{2}$

Most Indonesians, including moderate Muslim leaders, were very reluctant to acknowledge the radicals' activities in Indonesia. ${ }^{3}$ The 2002 Tempo Magazine survey revealed 32 percent of Indonesians were reluctant to acknowledge the existence of terrorist groups in Indonesia, yet 64 percent said otherwise. One year later, Tempo held another poll, focusing on the role of Jamaah Islamiyyah in the Marriott bombing. It revealed that 48 percent of respondents believed that Jamaah Islamiyyah was responsible for the blast, while 46 percent said otherwise. ${ }^{4}$ Both mentioned statistical data illustrate the decrease in the number of Indonesians who acknowledged the existence of the most dangerous militant Muslim groups in Southeast Asia. A similar pattern is found in the public opinion on the role of Abu Bakar Ba'asyir in certain bombings in Indonesia. The 2003 Tempo poll showed that 61 percent of the respondents assumed that he was involved in the attacks ${ }^{5}$ and the number decreased to 43 percent when Tempo held another poll on the same topic in $2004{ }^{6}$ To put this in a broader context, the above statistics might indicate the negative effect of the United States' war on terrorism and the military invasion of Afghanistan and Iraq. Moreover, the poll's

1 "Mozaik Teror Antar-Bangsa", in Tempo Magazine, Ed. 30/XXXI/23-29 September 2002 and "Lee Menuding, Jakarta Meradang", in Tempo Magazine, Ed. 52/ XXX/25 February- 03 March 2002.

2 “Mister Lee, Mana Buktinya?”, in Tempo Magazine, Ed. 01/XXXI/04-10 March 2002.

${ }^{3}$ R. William Liddle, "al-Faruq dan Indonesia”, in Tempo Magazine, Ed. 33/ XXXI/14 - 20 October 2002.

4 "Pengakuan JI yang Kurang Meyakinkan", in Tempo Magazine, Ed. 25/XXXII/18 - 24 August 2003.

5 "Presumed Guilty"in Tempo Magazine, Ed. 50/XXX/11 - 17 February 2003.

6 "Keragu-raguan atas Abu Bakar Ba'asyir", in Tempo Magazine, Ed. 37/XXXIII/08-14 November 2004. 
findings also suggest the successful campaign of many radical Indonesian Muslim organisations to drive public opinion to deny the presence of the Islamic radical movement, Jamaah Islamiyyah", and towards "winning the hearts and the minds of the people". ${ }^{8}$

This article attempts to present a comprehensive picture of a radical Muslim organisation which is accused of being responsible for many terror attacks. The discussion will begin with the historical background of Jamaah Islamiyyah, networks establishment and then to its current development during the Indonesian Reformation era (Era Reformasi).

\section{B. The Historical Background of the Establishment of Jamaah Islamiyyah}

Jamaah Islamiyyah takes its roots from Kartosuwiryo's struggle to establish an Indonesian Islamic state in the 1940s. Kartosuwiryo (1907-1962) is not an ulama in the traditional religious sense, but a student of a medical school in Surabaya in the 1920s, a period in which he became a close friend to Oemar Said Tjokroaminoto, president of the Indonesian Islamic Sarekat Party (Partai Sarekat Islam Indonesia/ PSII). Kartosuwiryo grew to prefer Islam, instead of nationalism, and proclaimed the Indonesian Islamic State, Darul Islam (DI), on 7 August 1949. After his 14 August 1945 proclamation of an Islamic state, which Kartosuwiryo himself revoked a few days later, he adhered to the leadership of Sukarno and joined the Masyumi (Majlis Syuro Muslimin Indonesia) Party.

${ }^{7}$ Hundreds Islamic radical organisations, like Front Pembela Islam (Islamic Front Defender), Komite Indonesia untuk Dunia Islam (Indonesian Committee for Islamic World) and Majelis Mujahidin Indonesia (MMI), contested the existence of militant organisations, initially that are responsible for violence and terror actions. They accused Israel and the US of being behind the attacks to discredit Muslims. In doing so, they came into the street and campaigned through media.

${ }^{8}$ Cees van Dijk, "The Hearts and the Minds of the People: Southeast Asia After 11 September 2001", paper at International Seminar: Islamic Militant Movements in Southeast Asia, Jakarta, 22-23 July 2003.

9 The accuracy of the 14 August 1945 proclamation of the Indonesian Islamic state, according to van Dijk, is doubtful because the geographical position of Jakarta relative to the area around Banten and Tasikmalaya where Kartosuwiryo was a supervisor of a Japanese-sponsored guerrilla training programme. Rumours of a forthcoming Japanese surrender in fact were confined to Jakarta and did not reach either Banten 
The confrontation between Kartosuwiryo and the Indonesian state began in early 1948 when the Siliwangi division of the regular army was withdrawn from West Java in accordance with the Renville Agreement between the central government and the Dutch. Kartosuwiryo led his Hizbullah ${ }^{10}$ unit to carry out guerrilla attacks and in January 1948, the group established itself as the Islamic Army of Indonesia (Tentara Islam Indonesia/TII). The tension was at its highest on 22 October 1950 when he demanded that President Sukarno abandon both Communism and Nationalism, return to Islam as the only ideology, and make al-Qur'an and the sunna (the Prophet's tradition) the constitution of his new Islamic republic.

In the 1950s, the Darul Islam rebellion spread widely across the archipelago. ${ }^{11}$ In South Sulawesi, Abdul Qahhar Mudzakkar joined Darul or Tasikmalaya. See, C. van Dijk, Rebellion Under the Banner of Islam: The Darul Islam in Indonesia (The Hague: Martinus Nijhoff, 1981), p. 14, B.J. Boland, The Struggle of Islam in Modern Indonesia (The Hague: Martinus Nijhof, 1982) p. 57, Keat Gin Ooi, Southeast Asia: A Historical Encyclopedia, from Angkor Wat to East Timor Vol. I (A-G) (California: Santa Barbara, 2004), p. 401 and Henri J.H. Alers, Om Een Rode of Grone Merdeka (Eindhoven: Uitgeverij Vulkaan Eindhoven, 1956), p. 240.

${ }^{10}$ Hizbullah is an irregular unit of the army founded by Islamic leaders in 1944 as a response to the Japanese-sponsored self defence units, the Defenders of Homeland (Pembela Tanah Air/Peta). It was a military unit with a complicated structure with many smaller factions inside, such as Muhammadiyah and Nahdlatul Ulama. Kartosuwiryo was the leader of a small faction in the unit. Refusing to go along with an agreement arrived at by the other nationalists with the Dutch that would have required the withdrawal of revolutionary forces from parts of Java, Kartosuwiryo led his unit to battle against the Dutch. In the following years, Kartosuwiryo's Hizbullah was part of the military rivalry between the regular and irregular forces, between armed forces led by Dutch and Japanese-trained officers. Ruth McVey, "The Post-Revolutionary Transformation of the Indonesian Army", Indonesia, 11 (April 1971), p. 138, Martin van Bruinessen, Genealogies of Islamic Radicalism in post-Suharto Indonesia"in http:// www.let.uu.nl/ Martin.vanBruinessen/personal/publications/genealogies_islamic_radicalism.htm (accessed, 17 July 2008), Cees Van Dijk, Rebellion Under the Banner of Islam: The Darul Islam in Indonesia, (The Hague: Martinus Nijhoff, 1981), Pinardi, Sekarmadji Maridjan Kartosuwirjo (Jakarta: Aryaguna, 1964), pp. 27-8, C.A.O. van Nieuwenhuijze, Aspects of Islam in Post Colonial Indonesia (The Hague: W. van Hoeve, 1958), p. 168.

${ }^{11}$ Darul Islam, according to Conboy, also attracted support from US Intelligence with a paramilitary program. The training was intended to restrain the ongoing powerful attraction of communism in Indonesia and to trigger a Muslim reaction towards the Soekarno presidency as well. See Ken Conboy, INTEL: Inside Indonesia's Intelligence Service (Jakarta: Equinox Publishing, 2004), p. 139. 
Islam in 1950 and was subsequently named National Deputy Minister of Defence of Darul Islam, leading a guerrilla war against the state. On 14 May 1963, Mudzakkar proclaimed the independence of East Indonesia as the Islamic Federated Republic of Indonesia (Republik Persatuan Islam Indonesia/RPII) with its centre in South Sulawesi. ${ }^{12}$ Following Mudzakkar, Daud Beureuh, the leader of the Union of All Acehnese Ulama (Persatuan Ulama-ulama Seluruh Aceh/PUSA), joined Darul Islam on 20 September 1953 on the twin grounds of preventing Aceh's absorption into the province of North Sumatra and the failure of the republic to implement Islamic law. The armed guerrilla war of Kartosuwiryo ended when the government launched a vigorous anti-guerrilla campaign in the period 1960-1962 and killed the leader. Mudzakkar's rebellion was halted on 3 February 1965 when he was killed in Lasolo, and Beureuh's campaign was finally brought to an end in 1962 through negotiations between the central government and Aceh rebel forces. ${ }^{13}$ As a result, Aceh was granted "Special Region" (Daerah Istimewa) status and the central government promised broad autonomy in the areas of religion, custom (adat) and education. ${ }^{14}$ However, the rebels then encouraged Hassan Tiro to declare the establishment of the Aceh Independence Movement (Gerakan Aceh Merdeka/GAM) in 1976. ${ }^{15}$

12 Tihami, M. A. Darul Islam di Masserengpulu: Studi Tentang Perubaban Sosial dan Keagamaan di Malua, Enrekang, Sulawesi Selatan (Makassar: Pusat latihan dan Penelitian Ilmu-ilmu Sosial, Hassanuddin University, 1984), p. 58, Abdul Qahhar Mudzakkar, Konsepsi Negara Demokrasi Indonesia: Koreksi Pemikiran Politik Pemerintahan Soekarno (Jakarta: Darul Falah, 1960).

${ }^{13}$ Anhar Gonggong, Abdul Qabhar Mudzakear: dari Patriot bingga Pemberontak (Yogyakarta: Ombak, 2004), p. 339.

${ }^{14}$ Rizal Sukma, "Secessionist Challenge in Aceh: Problems and Prospects" in Hadi Soesatro, at. al. (ed.), Governance in Indonesia: Challenges Facing the Megawati Presidency (Singapore: Institute of Southeast Asian Studies, 2003), pp. 165-166 and Arskal Salim, "'Sharia from below' in ACEH (1930s-1960s): Islamic identity and the right to self-determination with comparative reference to the Moro Islamic Liberation Front (MILF)", Indonesia and the Malay World, Vol. 32, No. 92, March 2004, pp. 80-99.

15 Different from Baureuh, Tiro was a former soldier who was disturbed by the way central authorities managed the natural resources of Aceh. He advocated for independence, not for religious purposes -if not to mention for the implementation of shari'ah-as Beureuh demonstrated but for economic and political reasons. Anthony Reid, An Indonesian Frontier: Acehnese and Other Histories of Sumatra (Singapore: Singapore University Press, 2005), p. 341 and Michelle Ann Miller, "The Nangroes Aceh Darus- 
As with Kartosuwiro, Mudzakkar and Beureuh, Masyumi was an Islamic party with the ideal of establishing an Indonesian Islamic state through implementing shari'a (Islamic Law). Instead of waging guerrilla war as Darul Islam, Masyumi had its own way of achieving this ideal: they sought to do so democratically and constitutionally. ${ }^{16}$ Since the abrogation of what would later be known as the "Seven Words formulation" of the Jakarta Charter, stating "Belief in Almighty God with the obligation for its Muslim citizens to carry out the Islamic law (Ketubanan yang maha Esa dengan kewajiban menjalankan syariah Islam bagi pemeluk-pemeluknya)", from the 1945 Indonesian constitution, ${ }^{17}$ Masyumi had demanded the re-application of the Jakarta Charter and opposed Soekarno due to his alliance with the Indonesian Communist Party (Partai Komunis Indonesia/PKI).

It was Prime Minister Muhammad Natsir who led Masyumi and became the leader in the struggle against communism in the 1950s. He also engaged in a campaign against Sukarno, whom he considered to be in favour of nationalism and secularism instead of Islam. The conflict between Natsir and Soekarno reached its peak after the 1955 election, which placed the Indonesian Communist Party in the fourth position in the election result, below the Indonesian Nationalist Party (Partai Nasionalis

salam Law: a Serious Response to Aceh", Asian Ethnicity, 15 (13), 2004, p. 343.

${ }^{16}$ B.J. Boland, The Struggle of Islam, p. 43 and David Jenkins, Subarto and His Generals; Indonesia Military Politics 1975-1983 (Ithaca, New York: Cornel Modern Indonesia Project, 1984), p. 9.

${ }^{17}$ On 22 June 1945, nine leading Indonesian leaders -known as "Nine Coordinators" (Panitia Sembilan)- collaborating in a Committee for the preparation of Indonesian Independence (Panitia Persiapan Kemerdekaan Indonesia/PPKI) had successfully drafted a constitution for a newly established republic. The draft is the second version of Pancasila -known as the Jakarta Charter (Piagam Jakarta)- and a reaction to the preceding version of Pancasila, which the future Indonesian president, Sukarno, promulgated in his speech known as "The Birth of the Pancasila" on 1 June 1945. On 18 August 1945, due to the objection of some political leaders, mainly those from the Eastern part of Indonesia of which a majority are Christians, the PPKI changed the formulation of the first sentence of Pancasila by removing the words "with the obligation of its Muslim citizens to carry out the shari'a". The first Sila became "Ketuhanan Yang Maha Esa” (the unity of God). Read, Jackson, Karl D., Traditional Authority, Islam and Rebellion: A Study of Indonesian Political Behaviour (Berkeley: University of California Press, 1980), p. 9 and Ahmad Syafi'i Ma'arif, Islam dan Politik; Teori Belah Bambu, Masa Depan Demokrasi Terpimpin (1959-1965) (Jakarta: Gema Insani Press, 1996), p. 29. 
Indonesia/PNI), Masyumi and Nahdlatul Ulama. The tension became increasingly heated after the 1957 regional elections, which placed the Indonesian Communist Party in the leading position in East Java. Finally on 15 February 1958, Natsir and many Indonesian Army officers, who at the time felt that Soekarno was a threat to Indonesian democracy and so were anti-Soekarno, proclaimed the establishment of the Revolutionary Government of the Indonesian Republic (Pemerintahan Revolusioner Republik Indonesia/PRRI) in Padang, West Sumatera. ${ }^{18}$ After Masyumi's involvement in PRRI, in the late 1950s, Sukarno proclaimed Masyumi an illegal party and officially forbade its leaders to hold their activities. Some of its leaders, such as Muhammad Natsir, were jailed and released in the 1960s.

The ideal of establishing an "Islamic state" had been the key notion of debate in the two decades of Indonesian independence. Proponents of an Indonesian Islamic state contested the idea of a "Pancasila"19 state which had become the Indonesian ideology since the independence, bridging a theocratic state, if not to mention an Islamic state, on the one hand and a secular state on the other. It was through the Jakarta Charter that Islamic proponents found themselves with the right political issue to revive the idea of an Islamic state. The aim of the debate over the charter was to ensure the appliance of Islamic law for Indonesian Muslim citizens, a political issue which nationalists, communists and non-Muslim groups were against. The heated debate culminated in 1959 when the Constituent Assembly (Majelis Konstituante) failed to reach a consensus concerning the state ideology and insisted that Soekarno would declare his "Guided Democracy" (1959-1965) by which the latter brought democracy under the authority of the president, closed the debate over the state ideology and announced a return to the 1945 constitution and Pancasila.

The presidential attitudes further generated strong opposition from Islamic groups and crystallised the demand for a democratic governmental system and a change of regime. The tension was exacerbated by concern

${ }^{18}$ R.Z Leirissa, "PRRI: Membangun Indonesia Tanpa Komunis (Building Indonesia without Communist)" in Tempo Magazine, Ed. 21/XXXVII/14 - 20 July 2008.

${ }^{19}$ Pancasila literally means "five pillars". It contains five principles; a belief in one Supreme being, a just and civilised humanitarianism, the unity of Indonesia, a people led by wise policies arrived at through a process of consultation and consensus and a commitment to social justice for all Indonesians. 
about the ongoing influential role of the Indonesian Communist Party at a grassroots level, threatening the authority of the religious elites (ulama) and the Indonesian Army. In addition, the state economy was in collapse and there was competition among leaders of the Indonesian Army; ${ }^{20}$ between the pro-Islam and nationalist cum communist factions. All together these concerns inflamed the opposition towards Soekarno.

It is worth mentioning that other factors contributing to the harsh opposition to Soekarno included the beginning of the Vietnam War in the late 1960s, the intensification of the Cold war in Southeast Asia ${ }^{21}$ and outside intervention, especially by the United States, which feared that communism would spread, domino-like, throughout Southeast Asia. ${ }^{22}$ As Anderson noted, the result of this fear was a series of U.S. initiatives aimed at incorporating Southeast Asian countries within its sphere of influence. Generally, these involved "creating loyal, capitalistically prosperous, authoritarian anti-communist regimes -typically, but not invariably, dominated by the military". ${ }^{23}$

The opposition culminated in the bloody events of the $30^{\text {th }}$ of September, in which six generals were killed during a night attack,

${ }^{20}$ Nasution was the mastermind behind the conflict within the Indonesian Army during the 1950s-1960s. On 11 November 1958, after being reappointed the chief of the Indonesian army staff, he gave a speech on the position of the army in society, being placed in all sectors and at the highest levels of government (the seed of the dual functions-dwi-fungsi of the Indonesian army during the New Order regime). Nasution's concern was to ensure that the military continued to exercise an influence in decision making and to keep the increasingly powerful Indonesian Communist Party at bay. He reportedly attended religious gatherings, gave sermons at Islamic feasts and invited Muslims to tackle the coming danger of communism. The conflict within the army culminated when, in mid 1962, Achmad Yani replaced his position and pledged to unite himself (menyatukan dir) "with the leadership of Bung Karno". Read, David Jenkins, Subarto and His Generals, p. 2-3 and Cees van Dijk, "the Resilience of Islam under Guided Democracy", unpublished Paper, presented at the seminar of Studiying Islam in Southeast Asia: State of the Art and New Approaches, Leiden, 7-8 July 2008.

${ }^{21}$ M. Ricklefs, A History of Modern Indonesia (Houndmills: Macmillan, 1981), pp. 259-269.

${ }^{22}$ W.W. Rostow, "The Case for the Vietnam War" in Parameters, Winter, 19961997, p. 39-50.

${ }^{23}$ Benedict Anderson, "From Miracle to Crash" in London Review of Books, Vol. 20/8, 1998, p. 16 and Donald S. Zagoria, "Who Fears the Domino Theory?" in Survival, 10:6 (June, 1968), p.184. 
allegedly as part of a coup by the Communist Party. Though Suharto may or may not have secretly instigated the coup, he rapidly gained advantages from the ensuing political clash. He encouraged rumours about the dangers of communism and the communists' plan to kill their enemies as demonstrated by the September coup. Consequently, Suharto was able to cultivate a "kill or be killed" atmosphere that incited people and set them up against communists. ${ }^{24}$

It was on 11 March 1966 that M. Jusuf, Brigadir Amir Machmud, and Brigadir Jendral Basuki Rahmat insisted that Soekarno, who was in Bogor at the time, should sign a letter in which the president would give General Suharto permission to take all steps necessary for the safety and stability of the state and government. The letter of the so-called the Order of March the Eleventh (Surat Perintah Sebelas Maret/Supersemar) caused a long tug-of-war between the president and the new leader concerning the duration of the transfer of authority. One year later, on 12 March 1967, Soeharto became the "acting president" and on 27 March 1969 was officially declared president for the next five years. The downfall of Soekarno signalled the end of the Old Order and emergence of the New Order under Suharto.

The political position of the New Order in the first decade of its political power was not as simple as it may seem. The government was traumatised by the ideological debates during the Old Order and also concerned about the existence of potentially rebellious Islamic groups. In order to secure his political position, Suharto decided first of all to stop the re-establishment of Masyumi by infiltrating the party. Ali Murtopo, the state intelligence chief, was the man behind the thwarting of the efforts of ex-Masyumi leaders, such as Sjafruddin Prawiranegara, Assaat, Prawoto Mangkusasmito, Moh. Roem, Kasman Singodimejo, Hamka dan Mohammad Natsir, to reinstall the Masyumi through the Coordinated Association of Muslim's Efforts (Badan Koordinasi Amal

${ }^{24}$ During the 1965 s, one hundred thousand to two million people, allegedly all Communist Party members, were killed. Hundreds of Islamic organisations, mainly the paramilitary body of Nahdlatul Ulama, the Anshar, as well as local gangsters such as jago, jawara and blater were involved in the genocide. Robert Cribb, "Unresolved Problems in the Indonesian Killings of 1965-1966" in Asian Survey, Vol. 42, No. 4, The Legacy of Violence in Indonesia (Jul. - Aug., 2002), pp. 552. 
Muslimin/BKAM). ${ }^{25}$ However, on 5 February 1969, the New Order government agreed to the establishment of the Indonesian Muslim Party (Partai Muslimin Indonesia/Parmusi) and in exchange, the government forbade former Masyumi leaders from leading the Parmusi. Due to the massive campaign by Golongan Karya (Golkar) in the 1971 election, not to mention intimidation by the government in support of Golkar, Parmusi lost and only managed to reach the fourth position after the Golkar, the Indonesian Nationalist Party (Partai Nasionalis Indonesia/ PNI) and Nahdlatul Ulama. ${ }^{26}$

Through a variety of means, Suharto also sent Ali Murtopo's Special Operations (Operasi Khusus/Opsus) to join forces with the Islamic state proponents in order to pull them onto his side, to then discredit them and make Golkar the winner of the 1977 election. Initially, Murtopo used the revived communism issue, after the Vietnam War ended in the 1970s, to make contact with the former leaders of Darul Islam, who were offered amnesty in 1963. In 1965, an Opsus officer, A. Sugiyanto established contact with Danu Mohammad Hasan, a high-ranking Darul Islam officer from West Java. ${ }^{27}$ Danu would later become the commander of Regional Command III of the Jihad Command (Komando Jihad) covering West Java. Further, Murtopo assigned Major Pitut Soeharto to handle the Jihad Command. As Opsus would later be dissolved within the newly-created State Coordinating Intelligence Agency (Badan Koordinasi Intelejen Negara/Bakin), Pitut would then lead the Special Operation (Operasi Khusus/Opsus) Directorate under Bakin's Deputy III, controlling the Jihad Command portfolio. In 1974, Danu was promoted to head the Java command and Haji Ismail Pranoto, alias Hispran, along with Kartosuwiryo's son, Dodo Mohammad Darda became the commander

${ }^{25}$ The Coordinated Association of Muslim Efforts (Badan Koordinasi Amal Muslimin/BKAM) founded on 16 December 1965 consists of sixteen Indonesian Muslim Organisations, among which are Muhammadiyah, Persatuan Islam (Persis), al-Irsyad, Persatuan Umat Islam, al-Ittihadiyah and Gabungan Serikat-serikat Buruh Islam Indonesia (Gasbindo). Hartono Mardjono, Politik Indonesia 1996-2003 Jakarta: Gema Insani Press, 1996), pp. 26-31.

${ }^{26}$ Abdul Azis Thaba, Islam dan Negara dalam Politik Orde Baru (Jakarta: Gema Insani Press, 1996), pp. 246-247.

${ }^{27}$ David Jenkins, Subarto and His Generals, pp. 56-60 and Ken Conboy, INTEL: Inside Indonesia's Intelligence Service, , p. 140. 
and the chief of staff respectively. ${ }^{28}$

Sometime in December 1976, Hispran and Taufiq, who introduced themselves as the representatives of Bakin, visited Pesantren Ngruki, an Islamic boarding school which Sungkar and Ba'asyir founded on 10 March 1972 and invited both clerics to join a movement which was intended to tackle the coming danger of communism in Indonesia. ${ }^{29}$ In that meeting, both Sungkar and Ba'asyir pledged an allegiance (bai'a $)^{30}$ to join the struggle with Hispran, who installed Sungkar as the head of Jamaah Anshorullah, a Jihad Command's branch operation in Central Java, and Ba'asyir as the vice leader. ${ }^{31}$

However, the government's plan to subjugate Sungkar and Ba'asyir was not successful. Instead of using the Jihad Command or Jamaah Ansharullah, Sungkar and Ba'asyir preferred to use "Jamaah

${ }^{28}$ The government's infiltration was not long lasting. Beginning in 1975, Anton Ngenget, a former member of the Indonesian Communist Party turned government informant, had been reporting that members of the Soviet Union consulate in Surabaya were encouraging the Indonesian Communist Party remnants to foster contact with the Jihad Command and Moscow was reportedly willing to provide military aid. Furthermore, that Jihad Command members would choose a Muslim party, the United Development Party (Partai Persatuan Pembangunan/PPP), not the Golkar in the 1977 election, made the government more open to attacking the group. In January 1977, four months ahead of the polls, security officials went on an offensive and eventually detained 185 persons by mid-year. Andrianus Harsawaskita and Evan A. Laksmana, "Rethinking Terrorism in Indonesia: Lessons from the 2002 Bali Bombing", UNISCI Discussion Paper, No. 5 (October 2007), pp. 73-74, Ken Conboy, INTEL: Inside Indonesia's Intelligence Service, pp. 144-5 and "Diakah Sang Imam?”, in Tempo Magazine, Ed. 35/ XXXI/28 October-03 November 2002.

${ }^{29}$ The Court Report of Sungkar's and Ba'asyir's trial in 1982, pp. 85-90.

${ }^{30}$ The bai'a text was the same text as the bai' $a$ text which Kartosuwiyo made in the 1940s, calling for the establishment of an Islamic state. It contains the following: "Bismillahirrahmannirrabim" "Ashadu ala Illaha Ilalloh, wa Ashaduanna Muhammadarrosulullah". I pledge allegiance to Allah, that I will obey my leader of Jamaah Mujabiddin Anshorullah as long as my leader obeys God and His messenger. And I promise and will always be (obeying): 1) Not to consider any ally beside Allah, 2) To conduct Shalat, 3) To fast in Ramadan, 4) Committing to all matters that Allah and His Messenger have already obliged and to restrain for committing all that they have probibited, 5) Committing to struggle in establishing God's religion... Allabu Akbar... Allahu Akbar... Allabu Akbar.

${ }^{31}$ Sungkar denied the bai' $a$ accusation which was voiced in the court. He acknowledged that the confession that he pledged allegiance to Hispran was due to pressure and torture. Ba'asyir mentioned the same. See, Sungkar's Speech in his 1982 court (10 March 1982), p. 14 and Ba'asyir Speech in his 1982 court (10 March 1982). 
Islamiyyah", naming their activities, and established networks with other former members of Darul Islam, such as Drs. Nuri Suharsono, Yusuf Latif and Abdul Qadir Baraja. The base for its political activities was in the salafi-pesantren of al-Mukmin, Ngruki. The activities of Jamaah Islamiyyah included publications and religious sermons which were held in Ngadiluwih, Matesih, and Karanganyar on each full moon of every month, often called Pengajian Sidi.

In the late 1970s, Ba'asyir circulated Risalah Jihad dan Hijrah (The Path of Jihad and hijra) which was written by his father-in-law, Abdul Qadir Baraja. It contains an explanation of the legal status of jihad in Islam and the obligation for Muslims to wage war against those who opposed the implementation of Islamic law in Indonesia. And in October 1976, Sungkar delivered a speech at the central mosque of Surakarta in which he publicly campaigned against participating in the 1977 elections and called for Golongan Putib/Golput (not to vote in the election). On 20 January 1978, Sungkar and Ba'asyir, in one of their sermons, publicly acknowledged and invited audiences to implement all aspects of the shari' $a$, and to replace both Pancasila and the 1945 Indonesia Constitution with al-Qur'an and the sunna, but not the Jakarta Charter, which eventually also appeared in their court explanations as a legitimate foundation and a reason for their declarations..$^{32}$ Due to their declarations, the Indonesian Police Department seized Sungkar on 10 November 1978 and Ba'asyir eleven days later on three counts: their involvement in the Indonesia Islamic State movement, their campaign against the Pancasila and persuading people not to participate in the election.

Following their detention, a series of violent crimes took place, all tied to people from Ngruki and Jamaah Islamiyyah. In January 1979, Musa Warman killed the assistant rector of the Eleventh of March University (Universitas Sebelas Maret) in Solo. The victim, according to the court documents, was accused of revealing the existence of Jamaah Islamiyyah to the authorities and therefore being responsible for the arrest of Sungkar and Ba'asyir. Warman reportedly also planned to kill the judge and prosecutor responsible for the conviction of Hispran who was

${ }^{32}$ Court's exceptions with the title "Idiologi Negara Pancasila, Gerakan Komunisme dan Ajaran Islam" (Ideology of Pancasila State, Communist Movement and Islam), of Sungkar and Ba'asyir in 1982. 
sentenced to life in prison for his Jihad Command activities in 1978. On 1 March 1979, Warman and a Ngruki teacher, Abdullah Umar, robbed a car that was used for transporting salaries of teachers at the State Islamic Institute of Sunan Kalijaga of Yogyakarta. On 21 March 1979, Warman and Umar attempted a second robbery in Malang. However, this attempt failed. Both robberies were undertaken on the basis of $f a$ ' $i$, raising funds by attacking enemies of Islam. ${ }^{33}$

In their 1982 court appearance, both Sungkar and Ba'asyir acknowledged that they were frustrated by the New Order's use of force towards Islamic groups to create acceptance of the Pancasila as the sole ideology (asas tunggal). Furthermore, the prohibition of ex-Masyumi leaders, such as M. Natsir and M. Roem, from participation in the Parmusi was considered as a plan of the government to defeat Islamic proponents. They were also frustrated by the illegitimate efforts of the government to persuade Indonesians to vote for the Golkar in the elections. Furthermore, they accused the government of disseminating incorrect faith which could endanger the Islamic faith, such as conserving many National Heroes' (Pablawan Nasional) tombs and defining October $1^{\text {st }}$ as the Celebration Day for the Sacred Pancasila (Hari Peringatan Kesaktian Pancasila). ${ }^{34}$ At the same time they acknowledged that they forbade their santri of Ngruki to hold any flag-ceremonies (upacara bendera) or salute the Indonesian flag, which was considered bid $a$ (innovation). ${ }^{35}$

In April 1982, the Regional Court (Pengadilan Negeri) of Surakarta sentenced both Sungkar and Ba'asyir to nine years of detention. Both appealed to the Provincial Court (Pengadilan Tinggi) which then reduced the sentence to three years and ten months detention, equivalent to their pre-trial detention, and they were released on 9 September 1982. The Provincial Court's decision left Sungkar and Ba'ayir dissatisfied and they brought another appeal to the Supreme Court (Mahkamah Agung/ MA), concerning the Provincial Court's decision. On 2 March 1985, when the Supreme Court was about to announce its decision, Sungkar

${ }^{33}$ International Crisis Group, al-Qaeda in Southeast Asia: the Case of the "Ngruki Network" in Indonesia, Brussels, 8 August 2002, pp. 7-8.

${ }^{34}$ Ibid., p. 11.

35 The Court Report of Sungkar's and Ba'asyir's trial in 1982, p. 100. 
and Ba'asyir did not show up in the court and made hijra (fleeing) ${ }^{36}$ to Malaysia. According to Ba'asyir, his hijra was necessary because the government illegitimately forced Indonesians to accept the Pancasila as the sole ideology. As he could not accept the government's programme and initially could not challenge it, Ba'asyir claimed that he had no choice but to make hijra. $^{37}$

During their two years of freedom in Central Java, prior to fleeing to Malaysia in 1985, Sungkar and Ba'asyir were able to extend Jamaah Islamiyyah's network through 'usra activists of the Sudirman Mosque (Masjid Sudirman) in Yogyakarta. The Masjid Sudirman, often known as Masjid Colombo, is well-known for its Islamic preachers (muballigh) who were as devoted to opposing the Suharto regime as they were to the strict implementation of shari'a law. Among the well-known muballighs associated with the Sudirman mosque were Irfan S. Awwas, M. Iqbal Abdul Rahman alias Fihiruddin Muqti alias Abu Jibril Abdurahman who later joined Sungkar's and Ba'asyir's hijra in Malaysia and became the instructor of the Abu Sayyaf camp in Afghanistan and Muchliansyah, a Ngruki teacher. ${ }^{38}$

In April 1985, Muchliansyah ordered Muzahar Muhtar, another activist from Masjid Sudirman, to accompany a group of Islamic activists avoiding the New Order government's oppression. The group included Sungkar, Ba'asyir and their loyalists, such as Fihiruddin Muqthie alias Abu Jibril Abdurrahman, Agus Sunarto, Ahmad Fallah, Rusli Aryus, Mubin

${ }^{36}$ Hijra means "to cut someone off from friendly association" or "to avoid association with". Historically, it is a political concept used by the Prophet Muhammad in order to avoid struggle with the people in Mecca, making his hijra to Medina where he established an Islamic community which eventually was used to attack his homeland. Therefore, bijra is not only a withdrawing action from the surroundings, but also as a strategy to fight back. See, Watt, W. Montgomery. "Hidjra." Encyclopaedia of Islam. Edited by: P. Bearman, Th. Bianquis, C.E. Bosworth, E. van Donzel and W.P. Heinrichs. Brill, 2008. Volume III, page 366, column 1.

${ }^{37}$ Irfan Suryahardi Awwas, Dakwah dan Jihad Abu Bakar Ba'asyir (Yogyakarta: Wihdah Press, 2003), pp. 37-38, "Hilangnya Sungkar Dan Ba'asyir" (the Disappearance of Sungkar and Ba'asyir) in Tempo Magazine, 16 March 1985, p. 24, "Ragam Kisah Ba'asyir dan Jaringan Ngruki” (Various Stories About Ba'asyir and his Ngruki Network) in Tempo Magazine, Ed. 36/XXXI/04-10 November 2002 and Bilveer Singh, The Talibanization of Southeast Asia: Losing the War on Terror to Islamist Extremists (Wesport etc.: Preager Security International, 2007), p. 63.

${ }^{38}$ International Crisis Group, al-Qaeda in Southeast Asia, pp. 9. 
Bustami, Fajar Siddiq and Agung Riyadi. ${ }^{39}$ Without full documentation or with false passports they took a land-route through Lampung, Sumatera where they stopped by and founded another Jamaah Islamiyyah's network, the so-called Mujahidin Community of The Right Path of Allah (Jamaah Mujahidin fi Sabilillah/JMF) ${ }^{40}$ whose ideal was to replace the Pancasila and the 1945 Indonesian Constitution with al-Qur'an and the sunna and to establish an Islamic state by overthrowing the legitimate government under Ba'asyir's father-in-law, Abdul Qadir Baraja. ${ }^{41}$

Upon their arrival in Malaysia, the group's settlement was arranged by a son-in-law of Abdul Qahhar Mudzakkar, Abdul Wahid Kadungga, one of the founders and the first head of the Europe-based Indonesian Muslim organisation, the Muslim Youth Association of Europe (Persatuan Pemuda Muslim se-Eropa/PPME) founded on 12 April $1971 .^{42} \mathrm{He}$ was the one who first introduced Sungkar and Ba'asyir to the transnational networks of Islamic movements. ${ }^{43}$

${ }^{39}$ Ibid., pp. 11-12.

40 Tatik S. Hafidz, "The War on Terror and The Future of Indonesian Democracy", unpublished paper at the Institute of Defence and Strategic Studies Singapore, March 2003, p. 7.

41 "Gerakan Separatis Belum Usai" (the Unfinished Separatist Movements) in Tempo Magazine, 18-24 Agust 2003, p. 81 and Abdul Azis Thaba, Islam dan Negara, p. 277.

${ }^{42}$ Kadungga was born in Palopo South Sulawesi, on 20 May 1940. He became a Dutch citizen living in Malaysia, neighbouring Sungkar and Ba'asyir in 1980s. In May 1971, Kadungga travelled to several Middle Eastern countries, such as Syria and Jordan. On 30 June 1973, he attended the international conference of the World Assembly of Muslim Youth (WAMY), the 1972 founded Saudi-affiliated Youth organisation, in Libya. In December 2002, he was arrested upon returning to Indonesia but was released after authorities ascertained that he had no role in the Bali bombings. PPME, The Muslim Youth Association of Europe's report, presented in the Indonesian Embassy in the Netherlands on 25-26 August 1973, pp. 1-11, "Abdul Wahid Kadungga: Akitivis Internasional”, in Suara Hidayatullah, October 2000 at http://www.hidayatullah.com/2001/10/siapa. shtml, Zachari Abuza, Militant Islam in Southeast Asia: Crucible of Terror (London: Lynne Rienner Publisher, Inc., 2003), pp. 126-127 and "Ragam Kisah Ba'asyir dan Jaringan Ngruki” (Various Stories About Ba'asyir and his Ngruki Network) in Tempo Magazine, Ed. 36/XXXI/04-10 November 2002 and "Sidney Jones: "Hambali Adalah Petinggi Al-Qaidah" (Sidney Jones: Hambali was al-Qaeda's top leader) in Tempo Magazine, Ed. 35/XXXI/28 October-03 November 2002.

43 “Jejak Ba'asyir di Sungai Manggis" (Ba'asyir's Steps in Manggis River) in Tempo Magazine, Ed. 35/XXXI/28 October-03 November 2002. 


\section{Establishing Networks}

In August 1985, the exiles held a series of meetings in which they decided to gain funds for the movement by asking their followers in Central Java to work in designated companies in Malaysia and turn over twenty percent of their salaries to the "jamaab". ${ }^{44}$ The exiles also decided to send Sungkar and Ba'asyir to Saudi Arabia to seek additional funds and, at the same time, decided to strengthen the Jamaah militarily by sending volunteers from Jakarta to be trained in Afghanistan. By 1987, the exiles had already sent six volunteers, supported by a Saudi-based foundation, the Rabita, to Pakistan's and Afghanistan's borders. ${ }^{45}$ The exiles' settlements served as way stations for Indonesians and Malaysians who were on their way to study at one of the forty al-Qaeda camps, the Jihad Fighters Academy of Afghanistan (Harbiy Pohatun Mujahidin-eAfghanistan Ittihad-e-Islamiy), run by the head of the Tanzim Ittihade-Islamiy Afghanistan, Abdul Robbir Rasul Sayyaf, and to participate in the Afghan war. ${ }^{46}$

The important person whose responsibility was to supply Indonesian cadres for training in Afghanistan was Ajengan Masduki, one of the very few senior leaders of Darul Islam with a Nahdlatul Ulama background. ${ }^{47}$ In 1986, when many leaders of the Darul Islam were arrested, he was appointed to be the imàm or 'amir (leader). Upon becoming the imàm, he made Haris the secretary, Abu Bakar Ba'asyir the minister of justice and Abdullah Sungkar responsible for foreign affairs.

${ }^{44}$ It is not clear whether by "jamaah" they were referring to members of the informal Ngruki network or to members of Jamaah Islamiyyah, but according to $\mathrm{Mu}-$ zahar who accompanied Sungkar and Ba'asyir in Malaysia in April 1985, the term refers to Jamaah Islamiyyah as an organisation which Sungkar and Ba'asyir founded prior to leaving Indonesia. International Crisis Group, al-Qaeda in Southeast Asia, pp. 11-2.

${ }^{45}$ Ibid., p. 12.

${ }^{46}$ Zachari Abuza, Militant Islam in Southeast Asia: Crucible of Terror, op. cit, 127 and Nasir Abas, Membongkar Jamaah Islamiyah: Pengakuan Mantan Anggota JI (Jakarta: Grafindo Khazanah Ilmu, 2005), pp. 47-48.

${ }^{47}$ Ajengan Masduki was born in Ciamis. In 1946, he fought in the Hizbullah unit against the Dutch and attended the 1946 Cisayeung, West Java meeting which laid the groundwork for the establishment of Darul Islam three years later. Masduki was arrested in 1982 because of his involvement in Komando Jihad and released in 1984. See, International Crisis Group, Recycling Militants in Indonesia: Darul Islam and the Australian Embassy Bombing, 23 February 2003, pp. 20-21. 
The main goals of Masduki's cabinet were to build international support and to strengthen Darul Islam's military capability. Sungkar focused on raising funds in the Middle East and Broto was assigned to streamline the sending of Darul Islam recruits to Afghanistan.

At some point in 1988, Masduki, accompanied by Sungkar and Ba'asyir, travelled to Afghanistan where they met with Abdul Robbir Rasul Sayyaf and Abdullah Azzam. The trip to Afghanistan had unforeseen consequences. The exposure to the Sayyaf circle provoked Masduki into thinking in terms of a caliphate as their ultimate objective, rather than the narrower goal of an Islamic state in Indonesia. Some Darul Islam cadres saw Masduki and his men deviating from Darul Islam's guidelines and others were displeased that Masduki behaved like a tourist (despite wearing trousers that covered the knees, Masduki insisted on going around the camp in shorts), that he could not speak Arabic, asking Sungkar to speak on behalf of the group, and that his preaching, from a salafi perspective, included objectionable superstition (ilmu laduni). ${ }^{48}$

The lengthy travel brought a consequence of the split between Sungkar and Masduki. It culminated in 1992 when Sungkar, a puritanical salafi, accused Masduki of sufism tendencies. Conversely, Masduki questioned Sungkar's accounting for the funds used for the Afghanistan training. He also said that Sungkar had personalised the Darul Islam induction oath so that now recruits swore loyalty to him rather than to the organisation. Moreover, Sungkar accused Ajengan Masduki of deviating from the Darul Islam and of collaborating with Ali Murtopo's right-hand, Adah Jaelani. ${ }^{49}$ The official split occurred on 1 January 1993 when Darul Islam's cadres in Afghanistan had to choose and to renew their oath or allegiance (bai $a$ ) to one of two imams. Those who preferred

${ }^{48}$ Ilmu laduni simply defined is God-given knowledge. The person with this knowledge is believed to know without learning and able to predict the future. Such belief is very popular among traditionalist Indonesian Muslims and most of the time it is identified as the kyai's supernatural capacity.

49 Adah Jaelani became the Darul Islam imam on 1 July 1979. Ajengan Masduki and Sungkar contested the appointment of the imam because he was accused of abandoning jihad. Since the death of Adah Jaelani, Darul Islam was divided into two broad factions; fillah, devoted to Adah Jaelani, and fisabilillah, who follow Ajengan Masduki and Abdullah Sungkar. "Surga di Pelupuk Mata" (Heaven just in the near eyes) in Tempo Magazine, Ed. 33/XXXII/13-19 October 2003 and International Crisis Group, Recycling Militants in Indonesia, pp. 10-1. 
to be on Ajengan Masduki side had to halt their military training in Afghanistan, but those who favoured Sungkar and Ba'asyir could continue the training. The event, according to Nasir Abbas, a Malaysian who joined the military camp in Afghanistan, signalled the official establishment of Jamaah Islamiyyah, which refers to the Sungkar faction, separated from Masduki’s Darul Islam. ${ }^{50}$

However, during their exile, Sungkar and Ba'asyir found a safe haven in Malaysia where they lived and preached openly. Sometime in the years between 1985 and 1999, they travelled to Singapore and delivered speeches in the Arabic School, the Islamic Center in Kampong Glam. ${ }^{51}$ Through sermons, they advocated the creation of dawla Islamiyya (Islamic state) which eventually would be transformed into kbiläfa Islämiyya $a^{52}$. In 1991, Sungkar and Ali Ghufron alias Mukhlas, later well-known as one of the masterminds of the 2002 Bali bombing, ${ }^{53}$ established the Pesantren Lukman al-Hakim in Johore ${ }^{54}$ and the Association of Malaysian Mujahidin (Kumpulan Mujahidin Malaysia/KMM). ${ }^{55}$ Through the pesantren and association, Sungkar and Ba'asyir attracted Malaysians and Indonesians to participate in the al-Qaeda military camp in Afghanistan, in Jamaah Islamiyyah's military camp in Mindano-Southern Philippines, Hudaibiyah

${ }^{50}$ Nasir Abas, Membongkar Jamaah Islamiyah, pp. 85-6.

51 "Stempel JI dari Singapura", in Tempo Magazine, Ed. 36/XXXI/04-10 November 2002.

52 “Suharto's Detect, Defect and Destroy Policy towards the Islamic Movements", interview with Abdullah Sungkar, Nida'ul Islam, February-March 1997 quoted in Zachari Abuza, Militant Islam in Southeast Asia, p. 127.

${ }^{53}$ On 12 October 2002, two coordinated bombs, the so-called Bali bombings, exploded in Sari Club and Paddy's Café, Legian-Kuta, Bali, killed 202 people with hundreds wounded.

${ }^{54}$ Sidney Jones, "The Changing Nature of Jemaah Islamiyah" in Australian Journal of International Affairs, Vol. 59, No. 2, June 2005, pp. 171.

${ }_{55}$ The KMM stems from the Association of Islamic Fighters of Perak (Kumpulan Perjuangan Islam Perak/KPIK) and the Association of the Kedah Jihad Fighters (Kumpulan Mujabidin Kedah/KMK), founded in 1988. The association was intended to establish the Malaysia Islamic state through military invasion. In the 1990 s, these associations were fused into the KMM which has as its objective, among others, to unify the former fighters of the Afghan War in Malaysia. Ibid. pp. 174-5 and "Al-Qaidah di Asia Tenggara?”, in Tempo Magazine, Ed. 47/XXX/21-27 January 2002. 
camp. ${ }^{56}$ All of this gave way to the establishment of Mujahidin alliance in Southeast Asia, the Rabitat al-Mujāhidin,,$^{57}$ and the formation of a joint coalition for their actions. With a loose alliance with other jihadist movements in Southeast Asia, such as the Moro Islamic Liberation Front (MILF) and the Abu Sayyaf Group (ASG), ${ }^{58}$ Jamaah Islamiyyah became an intermediary and important supporter of those movements and their attacks. ${ }^{59}$

In addition, Jamaah Islamiyyah is also believed to have strong ties to al-Qaeda. The connection started when Sungkar travelled to Afghanistan

${ }^{56}$ The Hudaibiyah camp in Mindano started its military training in December 1994. It is a military training of Jamaah Islamiyyah which was intended to train the MILF militias and a number of Indonesians and Malaysians. When the Philippine authorities attacked the camp, Jamaah Islamiyyah's training camp was moved to Poso at some point in 1999-2000. Abas, Membongkar Jamaah Islamiyah, pp. 148-51 and "Setapak Jejak Umar Al-Faruq", in Tempo Magazine, Ed. 31/XXXI/30 September-06 October 2002.

${ }^{57}$ See Sidney Jones, “The Changing Nature of Jemaah Islamiyah”, p. 171; Kumar Ramakrishna, "Delegitimizing Global Jihadi Ideology in Southeast Asia" in Contemporary Southeast Asia, 27, no. 3 (2005), p. 321, Rohan Gunaratna, "Ideology in Terrorism and Counter Terrorism: Lessons from combating Al Qaeda and Al Jemaah Al Islamiyah in Southeast Asia", p. 20, "Akhir Pelarian Hambali", in Tempo Magazine, Ed. 25/XXXII/18-24 August 2003.

${ }^{58}$ The relationship between Jamaah Islamiyyah, the MILF and Abu Sayyaf Group goes back to a key figure in the Afghanistan training camps, Fathur Rahman al-Ghozi aka Mike aka Randy Ali. Born on 17 Februari 1971 in Madiun, he studied in Ngruki from 1982-1989 before leaving to join military training in Afghanistan in 1990. It was in Afghanistan where he met Abdulrajak Janjalani, the founder of the Abu Sayyaf Group and became a close friend of two MILF fighters, Salahuddin and Habib, who worked with him on the so-called Rizal Day bombing, in December 2000. Al-Ghozi was detained in Manila since January 2002 on charges of illegal possession of explosives and falsification of documents. On 18 July 2003, al-Ghozi escaped from his detention centre in the Philippines and was shot to death three months later in Cotabaco City. See, Sidney Jones, "The Changing Nature of Jemaah Islamiyah", pp. 174-5; International Crisis Group, al-Qaeda in Southeast Asia, p. 2 , "Al-Ghozi Terantuk Bukti", in Tempo Magazine, Ed. 02/XXXI/11-17 March 2002, "Al-Qaidah "made in" Madiun?", in Tempo Magazine, Ed. 48/XXX/28 January-03 February 2002, "Fakta atau Propaganda Amerika?”, in Tempo Magazine, Ed. 48/XXX/28 January-03 February 2002 and International Crisis Group, Jemaah Islamiyah in Southeast Asia: Damaged but Still Dangerous, 26 August 2003, p. 6.

${ }^{59}$ Angel M. Rabasa, Political Islam in Southeast Asia: Moderates, Radicals and Terrorists (Oxford: Oxford University Press, 2003). 
and met Osama bin Laden in 1993-1994. ${ }^{60}$ Following Sungkar's meeting with Osama bin Laden, Ba'asyir and Sungkar charged Hambali and Abu Jibril with establishing a network of militant cells throughout Southeast Asia. Although Jamaah Islamiyyah was not a creation of al-Qaeda, its leadership looked to al-Qaeda for inspiration, training, and financial assistance during Jamaah Islamiyyah's formative years. In return, al-Qaeda gained the advantage of Jamaah Islamiyyah's covert infrastructure to support its attacks. In January 2000, some Jamaah Islamiyyah's members, including Hambali, had a meeting in Kuala Lumpur with several highlevel al-Qaeda operatives, including two 9/11 hijackers and others who were involved in planning the attack on the USS Cole in October $2000 .{ }^{61}$ Similarly, al-Qaeda's planned bomb attacks on U.S. and Western interests in Singapore in late 2001, which were eventually blocked, depended heavily on Jamaah Islamiyyah's clandestine infrastructure and local knowledge for surveillance of the targets and for building the truck bombs. ${ }^{62}$

In Indonesia, Jamaah Islamiyyah worked in tandem with many jihadist groups that were active in Indonesia's ongoing sectarian conflicts. ${ }^{63}$ During the Moluccas conflicts, they provided secure training facilities, increased logistical support and opportunities to undertake joint-operations for jihadist groups, such as Laskar Mujahidin, ${ }^{64}$ Laskar Jundullah ${ }^{65}$ and

${ }^{60}$ Rohan K. Gunaratna, Political and security outlook. 2003: Terrorism in Southeast Asia: What to Expect (Singapore: Institute of Southeast Asian Studies (ISEAS), 2003), p. 174.

${ }^{61}$ Zachary Abuza, Militant Islam in Southeast Asia: Crucible of Terror (Boulder, Colorado: Lynne Rienner, 2003), p. 123 and Rohan Gunaratna, Inside Al Qaeda: Global Network of Terror (New York: Columbia University Press, 2002), pp. 195-6.

${ }^{62}$ Brian A. Jackson, John C. Baker, et al., Aptitude for Destruction: Volume 2 (Case Studies of Organisational Learning in Five Terrorist Groups), p. 65.

${ }^{63}$ Tito Karnavian, at, al., Indonesia Top Secret: Membongkar Konflik Poso, Operasi dan Penindakan Pelaku Kekerasan di Sulawesi Tengah (Jakarta: Gramedia Pustaka Utama, 2008), pp. 174-5.

${ }^{64}$ Laskar Mujahidin was the most aggressive and well equipped militia in the Moluccas conflict. It was a loose alliance of a dozen minor Muslim paramilitary organisations that had been scattered among cities such as Solo, Yogyakarta, Kebumen, Purwokerto, Tasikmalaya and Makassar. See: Noorhaidi, Laskar Jibad: Islam, Militancy, and the Quest for Identity in Post-New Order Indonesia (Ithaca, NY: Cornell University, Southeast Asia Program, 2006) and Angel M. Rabasa, Political Islam in Southeast Asia, pp. 28-31.

${ }^{65}$ Laskar Jundullah was a regional militia in South Sulawesi, claiming a historical connection with the Darul Islam movement of that province. It was led by 
the Committee for Tackling Crisis (Komite Penanggulangan Krisis/ Kompak). ${ }^{66}$ It also built a strong connection and formed loose alliances with Indonesian pesantrens, such as pesantren al-Muttaqien in Jepara, Dar al-Sa'adah in Boyolali, al-Islam in Lamongan and pesantren Hidayatullah which has 127 branches around the archipelago. Several of those became places of shelter or transit for Jamaah Islamiyyah's member, of meetings and of transferring ideas. ${ }^{67}$

Apart from the above formal alliances, Jamaah Islamiyyah extended its networks through informal alliances, such as marriage. Therefore, it made Jamaah Islamiyyah resemble one large extended family. ${ }^{68} \mathrm{~A}$ number of marriages took place between Indonesians and Malaysians, showing a strong bond between the two peoples in the past few years during the exile. For instance, Ali Ghufron, one of the key operatives in the first Bali bombing, is married to the younger sister of Nassir bin Abbas, the former head of Jamaah Islamiyyah commander for Malaysia. Two of Ali Ghufron's brothers, Ali Imron and Amrozi, were deeply involved in the Bali bombing. Ali Fauzi, one of the Bali bombers, is Ali Ghufron's half-brother. Kinship bonds also extended to in-laws. Yazid Suffat became more religious through his wife's urging. He studied with senior members of Jamaah Islamiyyah, and ended up joining that organisation and was the host of the Kuala Lumpur al-Qaeda conference leading to the USS Cole bombing and the $9 / 11$ attacks. Haris Fadillah arranged the marriage of his daughter, Mira Agustina, to Umar al-Faruq, an al-Qaeda

Agus Dwikarna who was arrested in the Philippines, in March 2002. See: Martin van Bruinessen, "the Violent Fringes of Indonesia's radical Islam" in ISIM Newsletter, No. 11 (December 2002), p. 7, "Agus Dwikarna” in Tempo Magazine, Ed. 44/XXXI/30 December-05 January 2003.

${ }^{66}$ Kompak was a militant Muslim group in South Sulawesi headed by Tansil Linrung, a Dewan Dakwah Islamiyah Indonesia (DDII), the vice-leader of Komite Persiapan Penerapan Shari'at Islam (KPPSI) activist as well as one of high-ranking officers of the MMI. He was arrested on 11 March 2002 on charges of entering the Philippines illegally and the possession of explosives. See, "Al-Qaidah dari Makassar, Katanya" (Reportedly al-Qaeda from Makassar) in Tempo Magazine, Ed. 04/XXXI/25 - 31 March 2002 and “Tamsil Ditangkap, atau Dijebak?” (Tamsil: Arrested or trapped) in Tempo Magazine, Ed. 03/XXXI/18-24 March 2002.

${ }^{67}$ International Crisis Group, Jamaah Islamiyyah in Southeast Asia: Damaged but Still Dangerous, 26 August 2003.

${ }^{68}$ Bilveer Singh, The Talibanization of Southeast Asia, pp. 79-80. 
representative in Southeast Asia. ${ }^{69}$

In addition, as an organisation, Jamaah Islamiyyah consists of a structured leadership with the 'amir or supreme leader at the top level of the organisational body and the regional shirra as a consultative council of senior JI members. At the operational levels, Jamaah Islamiyyah consists of four territorial groups (mantiqis); mantiqi 1 is centred in Malaysia with a branch in Singapore; mantiqi 2 covers most of Indonesia and probably is the source of many JI operatives; mantiqi 3 has been important for training Jamaah Islamiyyah's personnel and supporting its logistical network; and mantiqi 4 is in Australia focusing primarily on recruiting and fundraising in the large Indonesian Diaspora community. ${ }^{70}$ While mantiqis are based on geographical commands, the lowest level of Jamaah Islamiyyah's structure, fi'ah (cell), is the ground-level and has more operational autonomy to take action. Furthermore, it seems that the fi'ah was significantly growing after the top-leaders of Jamaah Islamiyyah were under pressure and arrested by authorities during 1999-2004. In 2003, for instance, mantiqi 2 expanded into the district level (kabupaten) in their operation. In Central Java, it produced fi'ab for 6 regions (Pati, Semarang 1, Semarang 2, Kedu, Pekalongan and Banyumas) and successfully recruited

${ }^{69}$ Umar al-Faruq was born in Kuwait on 24 May 1971. He married Mira Agustina, a santri of pesantren al-Muttaqin, Jepara, Central Java, on 26 July. From his marriage, he has two children, now living with their mother in Cijeruk, Bogor, West Java. In 1990, he participated in the al-Qaeda Khaldan camp training and went to the Philippines where he taught at the Abu Bakar military training camp of the MILF. When the conflict between Muslims and Christians in Poso culminated in 2000, he taught Indonesian militias on military weapons and war strategies and was the master-mind behind the coordinated Christmas bombings in December 2000. He was arrested in Indonesia on 5 June 2002 and brought to the United States for interrogation. Noor Huda Ismail, "Understanding how Jihadists in Indonesia rejuvenate themselves", IRRI-paperpresented at IRII-KIIB (now The Royal Institute for International Relations) conference, Brussels on 30 March 2006, p. 7, "Dasamuka yang Gemar Menyaru”, in Tempo Magazine, Ed. 39/ XXXI/25 November-01 December 2002, "Rencana Besar Al-Faruq Al-Kuwaity", in Tempo Magazine, Ed. 30/XXXI/23-29 September 2002, "Setapak Jejak Umar Al-Faruq”, in Tempo Magazine, Ed. 31/XXXI/30 September - 06 October 2002 and "Jaringan Bom Laknat di Malam Kudus”, in Tempo Magazine, Ed. 2001-0//08 - 14 January 2001.

${ }^{70}$ Zachary Abuza, Militant Islam in Southeast Asia: Crucible of Terror (Boulder, Colorado: Lynne Rienner, 2003), Brian A. Jackson, John C. Baker, Aptitude for Destruction, p. 63. 
141 members. ${ }^{71}$ The growth of fi'ab is in tandem with the flourishing of Jamaah Islamiyyah's military cell-groups. For instance, Zulkarnaen, a former Afghan fighter as well as Ngruki's teacher, built the so-called Laskar Istimata $^{72}$ and Noordin M. Top (killed in 2009) and Azahari (killed in 2005), established Thoifah Muqatilah; ${ }^{73}$ both are suicide-troops of the Jamaah Islamiyyah. In July 2009, Noordin M. Top transformed the troop into Tandzim al-Qaida and initiated the second Marriot and Ritz hotels suicide bombings.

\section{A New Rupture?}

When Abdullah Sungkar died in November 1999, shortly after his return to Indonesia, Ba'asyir was named his successor as the head of Jamaah Islamiyyah. Some of Sungkar's recruits were very unhappy with the idea of Ba'ayir taking over. They were, amongst others, Riduan Isamuddin alias Hambali, Abdul Aziz alias Imam, Ali Gufron alias Muchlas and Abdullah Anshori alias Abu Fatih. They saw Ba'asyir as too weak, too accommodating and too easily influenced by others. ${ }^{74}$ The split worsened when Ba'asyir, together with Irfan Suryahardi Awwas, founded the Majelis Mujahidin Indonesia (MMI) in August 2000. This rupture among the activists of Jamaah Islamiyyah is understandable for three reasons. Firstly, according to the Operation Manual of Jamaah Islamiyyah, the General Guide for the Struggle of Jamaah Islamiyyah (Pedoman Umum Perjuangan Jamaah Islamiyyah/PUPJI), Jamaah Islamiyyah is a tandim al-sirr (secret organisation) and the establishment of the MMI was deviating from this fundamental stipulation. Secondly, the establishment of the MMI brings activists to the soft movement which is clearly contested through PUPJI. Thirdly and consequently, the military

71 "Satu Ton Bom di Kios Sandal", in Tempo Magazine, Ed. 33/XXXII/13-19 October 2003.

72 "Jenderal Laskar Istimata", in Tempo Magazine, Ed. 33/XXXII/13-19 October 2003.

73 "Azahari Diburu, Azahari Merekrut", in Tempo Magazine, Ed. 33/XXXIV/10-16 October 2005, "Sayap Garis Keras itu Bernama Thoifah Muqatilah”, in Tempo Magazine, Edisi. 34/XXXIV/17 - 23 Oktober 2005.

${ }^{74}$ International Crisis Group, Indonesia Backgrounder: How the Jamaah Islamiyyah Terrorist Network Operates, 11 December 2002, p. 3 and "Komplotan Baru Pak Guru Dujana”, in Tempo Magazine, Ed. 07/XXXIIIIII/09-15 April 2007. 
operation methods, which were described and prescribed in the PUPJI, consequently would be abandoned. ${ }^{75}$ Therefore, Abu Dujana, the former secretary of Abdullah Sungkar in Jamaah Islamiyyah, accused Ba'asyir of deviating from Abdullah Sungkar and the nature of Jamaah Islamiyyah. ${ }^{76}$

Prior to the first Bali Bombings in 2002, some meetings reportedly were held in Surabaya, Lamongan, Mojokerto and other places, between the MMI and Jamaah Islamiyyah activists. Ba'asyir urged that bombing and armed struggle for an Islamic state should be put on hold for the time being because they would have negative repercussions for the movement. ${ }^{77}$ Ba'asyir's advice was poorly received among Jamaah Islamiyyah's members and, while continuing to show respect and acknowledging him as the head of Jamaah Islamiyyah, they began searching for a new leader, closer to their way of thinking. Some names arose to replace Ba'asyir, such as Thoriquddin alias Abu Rusdan alias $\mathrm{Hamzah}^{78}$ and Abu Dujana alias Ainul Bahri alias Yusron Mahmud. ${ }^{79}$

Although Ba'asyir's leadership was contested by a number of Jamaah Islamiyyah activists, he received much respect from other Jamaah Islamiyyah activists. He was the de jure leader of Jamaah Islamiyyah. Samudra and Mukhlas, two perpetrators of the Bali bombings, for instance, met Ba'asyir in 2003 to get permission from the 'amir to commit the Bali bombings. Likewise, Ba'asyir has shown his sympathy toward the perpetrators of the bombings. On 15 December 2007, Ba'asyir, together with thirteen members of the MMI, visited Imam Samudra and Muchlas, the two master-minds of the Bali bombings, in their detention centres. On many occasions, $\mathrm{Ba}$ 'asyir pronounced in the media that those who killed

${ }^{75}$ Al-Jamaah al-Islamiyyah, The General Guide for the Struggle of Jamaah Islamiyyah (Pedoman Umum Perjuangan Jamaah Islamiyyah/PUPJI), 30 May 1996, and "Surga di Pelupuk Mata", in Tempo Magazine, Ed. 33/XXXII/13-19 October 2003.

76 "Abu Dujana: Saya Marah kepada Noor Din”, in Tempo Magazine, Ed. 17/ XXXIIIIII/18-24 June 2007.

${ }^{77}$ Abu Bakar Ba'asyir at the center of controversy " at http:/ / wmm.thejakartapost. com/news/2003/03/08/abu-bakar-ba039asyir-center-controversy. html (accessed 1 November 2008).

78 "Abu Rusdan: Kehebatan Abu Dujana Hanyalah Imajinasi", in Tempo Magazine Ed. 06/XXXIIIIII/02-8 April 2007.

${ }^{79}$ Zachary Abuza, “Abu Dujana: Jamaah Islamiyyah's New al-Qaeda Linked Leader", Jamestown Foundation, Terrorism Focus, 3 (13), 4 April 2006. 
themselves in the Marriott bombing and the Bali bombings are martyrs. ${ }^{80}$ Similarly, the head of MMI, Awwas, also showed a half-hearted stance towards the perpetrators of the bombings. In spite of condemning the perpetrators, Awwas accused the United States of threatening, through a global campaign against terrorism, Islamic movements that are devoted to their mission to establish shari' a. ${ }^{81}$ On 10 March 2002, the MMI issued an "official opinion on international terrorism" endorsing terrorism and in reverse accused the US of being a "terrorist state". The official opinion itself was claimed as a result of a consensus among MMI's leaders and was signed by its top leader, the so-called 'amir al-mujähidin, Abu Bakar Ba'asyir. ${ }^{82}$

The relationship between Ba'asyir and the MMI lasted eight years until suddenly Ba'asyir resigned from his position as the 'amir of the MMI on 19 July 2008 and founded Jamaah Ansharut Tauhid (JAT) on 17 September 2008. ${ }^{83}$ The resignation was caused by a disagreement between Ba'asyir and Awwas about authority and control over the MMI. ${ }^{84}$ The public appearance for the resignation was the model of leadership of $A b l$ al-Hal wa'-A 'Aqd (AHWA), a supreme body of the MMI which Ba'asyir himself led. Through his fatwā, Ba'asyir argues that the MMI's structure of organisation follows the "Jewish tradition" (sunnab Yahudi), not the imäma by which an 'amir can act and decide freely as he proposed. ${ }^{85}$. Therefore, the 'amir is able to act with or without first consulting on the decision with the AHWA members, and has the authority to take

80 "Ba'asyir Keluarkan Fatwā Al Ghozi Mati Syahid", in http:/ / wmw.tempointeraktif. com/ hg/nasional/2003/10/18/brk,20031018-10,id.html, accessed 9 June 2008.

${ }^{81}$ Irfan S. Awwas, "Menegakkan Syariat tanpa Teror", in Tempo Magazine, Ed. 38/XXXI/18-24 November 2002.

${ }^{82}$ Majelis Mujahidin Indonesia, Official Opinion on International Terrorism, issued on 10 March 2002.

83 "Kepenatan itu Terbayar", in http:/ / abbcenter.org/ index.php?option=com_content

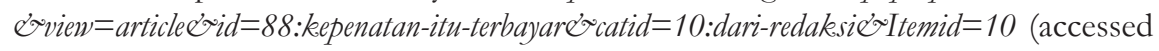
8 October 2008).

84 "Ustad Berpisah Jamaah Terbelah", in Gatra Magazine, No. 39 /XIV 13 August 2008.

${ }^{85}$ Jamaah Islamiyyah also the imàma model as declared in the PUPJI. See, AlJamaah al-Islamiyyah, Pedoman Umum Perjuangan Jamaah Islamiyyah (Majlis Qiyadah Markaziyah), 30 May 1996, chapter 24: point 7 and pp. 5-6 and Zachary Abuza, "The State of Jamaah Islamiyyah" in The Fletcher Forum of World Affairs, Vol. 28:1, Winter 2004, p. 96. 
any decision, even when other council members do not agree with his decision. ${ }^{86}$ Responding to Ba'asyir's fatwā, Awwas accused Ba'asyir of being arrogant and forcing his own perspective on the MMI. The MMI is not deviating from the shari' $a$, it deviates from Ba'asyir's point of view. ${ }^{87}$ Furthermore, M. Thalib, the new 'amir of the MMI, claimed Ba'asyir's model of leadership followed Shiite-Islam, the Ahmadiyah, as well as being a Communist model of leadership. ${ }^{88}$

Apart from the above-mentioned reasons, there might be another factor behind the resignation of Ba'asyir, namely the hijra creed which Ba'asyir said was the core method of his struggle, Jamaah Islamiyyah's model of strengthening military power through establishing the truthful community or even by flight to the safe area as mentioned throughout the PUPJI. To do so, in 2006, Ba'asyir published a book with the name "Notes from the Prison to Uphold and Establish Islam" (Catatan dari Penjara untuk. Mengamalkan dan Menegakean Dinul Islam) in which he emphasises again the importance of the hijra method. ${ }^{89}$ Therefore, it seems that Ba'asyir was dissatisfied with the MMI, which was becoming more and more involved in politics through its activities and leaving the creation of a truly Islamic community and bijra doctrine aside. ${ }^{90}$ In other words, the MMI has deviated from truthful methods of establishing religion and become a counter-state movement instead of a counter-

86 “Abu Bakar Ba'asyir: Ini Pembunuhan Karakter", in Gatra Magazine, No. 39/XIV 13 August 2008, "Surat Pernyataan Amirul Mujahidin Abu Bakar Ba'asyir" (Official Letter of Amirul Mujahidin, Abu Bakar Ba'asyir) in http://abbcenter.org/

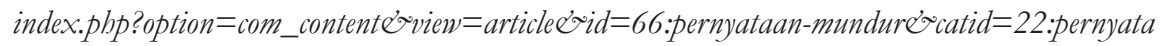
anङItemid=59 (accessed 8 October 2008), "Ustad Ba'asyir Mengundurkan Diri dari Majelis Mujahidin", http:// wnw.eramuslim.com/ berita/ nas/8805155942-ustad-ba039asyirmengundurkan-diri-majelis-mujabidin.htm (accessed 6 August 2008).

87 “Ustadz Abu Bakar Ba'asyir Disuruh Mundur Irfan”, at http://infojihad. wordpress.com/2008/08/07/ustadz-abu-bakar-baasyir-disurub-mundur-irfan/ (accessed 10 August 2008) and "Pimpinan MMI Harapkan Ba'asyir Hadiri Kongres", in Republika, 8 August 2008, “Kongres MMI Tanpa Ba'asyir”, in Suara Merderka, 10 August 2008, "Kepenatan itu Terbayar".

88 "Muhammad Thalib: Syiah, Ahmadiyah dan Komunis", in Gatra Magazine ed. 39/XIV 13 August 2008.

${ }^{89}$ Abu Bakar Ba'asyir, Catatan dari Penjara: Untuk Mengamalkan dan Menegakkan Dinul Islam (Depok: Mushaf, 2006).

${ }^{90}$ Syaifudin Zuhri, "Majelis Mujahidin Indonesia: Ideology, Militancy and Polie tics”, MA Thesis, Leiden University, 2009. 
society movement as mentioned throughout the de facto manifesto and operational practices of Jamaah Islamiyyah. ${ }^{91}$

However, it is interesting to examine the post-Ba'asyir MMI. Unlike when it was under Ba'asyir, the current MMI was not involved in defending the Bali bombing perpetrators a few days prior to their execution on 8 November 2008. Instead of organising a demonstration against the death execution or delivering a fatwa like Ba'asyir's JAT did, the MMI did not respond to this issue. Contrary to the MMI, the JAT accused the government of killing truthful mujahidin when the perpetrators were shot to death. Another important development of the MMI is that it shows a willingness to uncover the controversy concerning the existence of Jamaah Islamiyyah, different form the previous MMI's stance when it denied its existence. This can be seen from a comment of the new leader of the MMI, Muhammad Thalib, who acknowledges that there are three powerful factions within the MMI that tried to control the organisation; the Indonesian military, Jamaah Islamiyyah, and the MMI. ${ }^{92}$ This contemporary development needs further research, including the post-Ba'asyir era of the MMI and the JAT that increasingly gained sympathy and members, particularly after the execution of the first Bali bombing perpetrators.

\section{E. Conclusion}

The aforementioned episodes reveal that Jamaah Islamiyyah stems from the Kartosuwiryo's Darul Islam rebellion in the 1940s, which had as its main objective the establishment of an Indonesian Islamic state. During the New Order regime, this ideal was revived by the Darul Islam-like, Jihad Command, which was the creation of Ali Murtopo, who initiated former activists of Darul Islam into organising themselves.

${ }^{91}$ Pavlona differentiates between "a counter-society" and "a counter-state movement". The differentiation is made on the basis of the stated goals and objectives of the movement. The latter typically refers to movements that violently challenge or seek to overthrow the existing structures of power, the state and its governing apparatus. The former connotes movements that conceptualise themselves primarily as alternative forms of social collectivity and organisation rather than confront the state directly. Elena Pavlona, "From Counter-Society to a Counter-State Movement: Jemaah Islamiyyah According to PUPJI" in Studies in Conflict and Terrorism, 30/2007, p. 778.

${ }^{92}$ Muhammad Thalib, "Syiah Ahmadiyah dan Komunis". 
From the New Order government's point of view, the creation of Jihad Command was intended to break up the Islamic party voters in the 1977 elections and to attract Islamic voters to choose the Golkar. Despite following the state's scenario, Jihad Command turned against the government, contested the government's initiation of Pancasila as the sole ideology and made a loose alliance among activists under the banner of Jamaah Islamiyyah, headed by Abdullah Sungkar and Abu Bakar Ba'asyir.

In 1985, Sungkar and Ba'asyir fled to Malaysia where they continuously campaigned against the government, sent hundreds of Indonesians and Malaysians for military training with al-Qaeda leaders and participation in the Afghanistan war (1979-89). The battlefield created links between both clerics and their followers and other Islamic militants in the Middle East and in Southeast Asia. It was in 1993 that Sungkar and Ba'asyir transformed Jamaah Islamiyyah into a transnational jihadist group with the ideal of establishing khilafa through jibad and organized terror attacks in Southeast Asia.

In 1999, when the Reformation era (era reformasi) had just begun, Ba'syir and Sungkar went back to Indonesia. In the same year, the 'amir of Jamaah Islamiyyah passed away and his position was taken by Abu Bakar Ba'asyir. From the very beginning, some militants within Jamaah Islamiyyah contested Ba'asyir's leadership. It worsened when Ba'asyir, together with his old cadre and network of 'usra activists, Irfan Suryahardi Awwas, and some Jamaah Islamiyyah's actitivists founded MMI, which became the public face of Jamaah Islamiyyah, thereby integrating some parts of Jamaah Islamiyyah into the new Indonesian politics. The cooperation of Ba'asyir and MMI endured for eight years until suddenly Ba'asyir resigned from his position as top leader of the MMI and founded his JAT in September 2008. In this way, he gained full control of the organisation, demonstrated his invaluable respect to his cadres, who committed and initiated terror attacks, and established the counter-society movement as his method of struggle. 


\section{BIBLIOGRAPHY}

Abas, Nasir, Membongkar Jamaah Islamiyah: Pengakuan Mantan Anggota JI, Jakarta: Grafindo Khazanah Ilmu, 2005.

Abuza, Zachari, Militant Islam in Southeast Asia: Crucible of Terror, London: Lynne Rienner Publisher, Inc., 2003.

----, “Abu Dujana: Jamaah Islamiyyah's New al-Qaeda Linked Leader", Jamestown Foundation, Terrorism Focus, 3 (13), 4 April 2006.

----, "The State of Jamaah Islamiyyah," The Fletcher Forum of World Affairs, Vol. 28:1, Winter 2004.

Alers, Henri J.H., Om Een Rode of Grone Merdeka, Eindhoven: Uitgeverij Vulkaan Eindhoven, 1956.

Anderson, Benedict, "From Miracle to Crash," London Review of Books, Vol. 20/8, 1998.

Awwas, Irfan Suryahardi, Dakwah dan Jihad Abu Bakar Ba'asyir, Yogyakarta: Wihdah Press, 2003.

Ba'asyir, Abu Bakar, Catatan dari Penjara: Untuk Mengamalkan dan Menegakekan Dinul Islam, Depok: Mushaf, 2006.

Boland, B.J., The Struggle of Islam in Modern Indonesia, The Hague: Martinus Nijhof, 1982.

Brian A. Jackson, John C. Baker, et al., Aptitude for Destruction: Volume 2 (Case Studies of Organisational Learning in Five Terrorist Groups)

Bruinessen, Martin van, "the Violent Fringes of Indonesia's radical Islam," ISIM Newsletter, No. 11 (December 2002)

Conboy, Ken, INTEL: Inside Indonesia's Intelligence Service, Jakarta: Equinox Publishing, 2004.

Cribb, Robert, "Unresolved Problems in the Indonesian Killings of 1965-1966," Asian Survey, Vol. 42, No. 4, The Legacy of Violence in Indonesia (Jul. - Aug., 2002)

Dijk, Cees van, "The Hearts and the Minds of the People: Southeast Asia After 11 September 2001", Unpublished Paper at International Seminar: Islamic Militant Movements in Southeast Asia, Jakarta, 22-23 July 2003. ----, Rebellion Under the Banner of Islam: The Darul Islam in Indonesia, The 
Hague: Martinus Nijhoff, 1981.

----, "the Resilience of Islam under Guided Democracy", Unpublished Paper, presented at the seminar of Studiying Islam in Southeast Asia: State of the Art and New Approaches, Leiden, 7-8 July 2008.

Gonggong, Anhar, Abdul Qabhar Mudzakkar: dari Patriot hingga Pemberontak, Yogyakarta: Ombak, 2004.

Gunaratna, Rohan, "Ideology in Terrorism and Counter Terrorism: Lessons from combating $\mathrm{Al}$ Qaeda and $\mathrm{Al}$ Jemaah Al Islamiyah in Southeast Asia"

----, Inside Al Qaeda: Global Network of Terror, New York: Columbia University Press, 2002.

----, Political and security outlook 2003: Terrorism in Southeast Asia: What to Expect, Singapore: Institute of Southeast Asian Studies (ISEAS), 2003.

Hafidz, Tatik S., "The War on Terror and The Future of Indonesian Democracy," Unpublished Paper at the Institute of Defence and Strategic Studies Singapore, March 2003.

Harsawaskita, Andrianus and Evan A. Laksmana, "Rethinking Terrorism in Indonesia: Lessons from the 2002 Bali Bombing”, UNISCI Discussion Paper, No. 5 (October 2007)

Hasan, Noorhaidi, Laskar Jihad: Islam, Militancy, and the Quest for Identity in Post-New Order Indonesia, Ithaca, NY: Cornell University, Southeast Asia Program, 200.

International Crisis Group, al-Qaeda in Southeast Asia: the Case of the "Ngruki Network" in Indonesia, Brussels, 8 August 2002.

----, Indonesia Backgrounder: How the Jamaah Islamiyyah Terrorist Network. Operates, 11 December 2002.

----, Jemaah Islamiyah in Southeast Asia: Damaged but Still Dangerous, 26 August 2003.

----, Recycling Militants in Indonesia: Darul Islam and the Australian Embassy Bombing, 23 February 2003, pp. 20-21.

Ismail, Noor Nuda, "Understanding how Jihadists in Indonesia rejuvenate themselves", IRRI-paper presented at IRII-KIIB (now The Royal Institute for International Relations) conference, Brussels on 
30 March 2006.

Jackson, Karl D., Traditional Authority, Islam and Rebellion: A Study of Indonesian Political Behaviour, Berkeley: University of California Press, 1980.

Jenkins, David, Suharto and His Generals; Indonesia Military Politics $1975-$ 1983, Ithaca, New York: Cornel Modern Indonesia Project, 1984.

Jones, Sidney, "The Changing Nature of Jemaah Islamiyah," Australian Journal of International Affairs, Vol. 59, No. 2, June 2005.

Karnavian, Tito, et al., Indonesia Top Secret: Membongkar Konflik Poso, Operasi dan Penindakan Pelaku Kekerasan di Sulawesi Tengah, Jakarta: Gramedia Pustaka Utama, 2008.

Ma'arif, Ahmad Syafi'i, Islam dan Politik; Teori Belah Bambu, Masa Depan Demokrasi Terpimpin (1959-1965), Jakarta: Gema Insani Press, 1996.

Mardjono, Hartono, Politik Indonesia 1996-2003, Jakarta: Gema Insani Press, 1996.

McVey, Ruth, "The Post-Revolutionary Transformation of the Indonesian Army," Indonesia, 11 (April 1971)

Miller, Michelle Ann, "The Nangroes Aceh Darussalam Law: a Serious Response to Aceh," Asian Ethnicity, 15 (13), 2004.

Mudzakkar, Abdul Qahhar, Konsepsi Negara Demokrasi Indonesia: Koreksi Pemikiran Politik Pemerintahan Soekarno, Jakarta: Darul Falah, 1960.

Nieuwenhuijze, C.A.O. van, Aspects of Islam in Post Colonial Indonesia, The Hague: W. van Hoeve, 1958.

Ooi, Keat Gin, Southeast Asia: A Historical Encyclopedia, from Angkor Wat to East Timor Vol. I (A-G), California: Santa Barbara, 2004.

Pavlona, Elena, "From Counter-Society to a Counter-State Movement: Jemaah Islamiyyah According to PUPJI," Studies in Conflict and Terrorism, 30/2007.

Pinardi, Sekarmadji Maridjan Kartosuwirjo, Jakarta: Aryaguna, 1964.

Rabasa, Angel M., Political Islam in Southeast Asia: Moderates, Radicals and Terrorists, Oxford: Oxford University Press, 2003.

Ramakrishna, Kumar, "Delegitimizing Global Jihadi Ideology in Southeast Asia," Contemporary Southeast Asia, 27, no. 3 (2005) 
Reid, Anthony, An Indonesian Frontier: Acehnese and Other Histories of Sumatra, Singapore: Singapore University Press, 2005.

Ricklefs, M.C., A History of Modern Indonesia, Houndmills: Macmillan, 1981.

Rostow, W.W., “The Case for the Vietnam War," Parameters, Winter, 1996-1997.

Salim, Arskal, “'Sharia from below' in ACEH (1930s-1960s): Islamic Identity and the Right to Self-determination with Comparative Reference to the Moro Islamic Liberation Front (MILF)," Indonesia and the Malay World, Vol. 32, No. 92, March 2004.

Singh, Bilveer, The Talibanization of Southeast Asia: Losing the War on Terror to Islamist Extremists, Wesport etc.: Preager Security International, 2007.

Sukma, Rizal, "Secessionist Challenge in Aceh: Problems and Prospects" in Hadi Soesatro, at. al. (ed.), Governance in Indonesia: Challenges Facing the Megawati Presidency, Singapore: Institute of Southeast Asian Studies, 2003.

Thaba, Abdul Azis, Islam dan Negara dalam Politik Orde Baru, Jakarta: Gema Insani Press, 1996.

Tihami, M. A. Darul Islam di Masserengpulu: Studi Tentang Perubahan Sosial dan Keagamaan di Malua, Enrekang, Sulawesi Selatan, Makassar: Pusat latihan dan Penelitian Ilmu-ilmu Sosial, Hassanuddin University, 1984.

Watt, Montgomery, "Hidjra", Encyclopaedia of Islam. Edited by: P. Bearman, Th. Bianquis, C.E. Bosworth, E. van Donzel and W.P. Heinrichs. Brill, 2008.

Zagoria, Donald S., "Who Fears the Domino Theory?," Survival, 10:6 (June, 1968)

Zuhri, Syaifudin, "Majelis Mujahidin Indonesia: Ideology, Militancy and Politics," MA Thesis, Leiden University, 2009

\section{Newspaper, Magazines, Documents and the Internet}

"Abdul Wahid Kadungga: Akitivis Internasional", in Suara Hidayatullah, October 2000 at http:/ / wmw. hidayatullah.com/2001/10/siapa.shtml. 
"Abu Bakar Ba'asyir: Ini Pembunuhan Karakter", in Gatra Magazine, No. 39/XIV 13 August 2008.

"Abu Dujana: Saya Marah kepada Noor Din”, in Tempo Magazine, Ed. 17/XXXIIIIII/18-24 June 2007.

“Abu Rusdan: Kehebatan Abu Dujana Hanyalah Imajinasi”, in Tempo Magazine Ed. 06/XXXIIIIII/02-8 April 2007.

“Agus Dwikarna”, in Tempo Magazine, Ed. 44/XXXI/30 December-05 January 2003.

"Akhir Pelarian Hambali”, in Tempo Magazine, Ed. 25/XXXII/18 - 24 August 2003.

"Al-Ghozi Terantuk Bukti", in Tempo Magazine, Ed. 02/XXXI/11-17 March 2002.

"Al-Qaidah "made in" Madiun?”, in Tempo Magazine, Ed. 48/XXX/28 January-03 February 2002.

"Al-Qaidah dari Makassar, Katanya", in Tempo Magazine, Ed. 04/XXXI/25 - 31 March 2002.

“Al-Qaidah di Asia Tenggara?”, in Tempo Magaz̨ine, Ed. 47/XXX/21-27 January 2002.

"Azahari Diburu, Azahari Merekrut", in Tempo Magazine, Ed. 33/ XXXIV/10-16 October 2005.

"Ba'asyir Keluarkan Fatwā Al Ghozi Mati Syahid", in http://www. tempointeraktif.com/ hg/nasional/2003/10/18/brk,20031018-10,id.html, accessed 9 June 2008.

"Dasamuka yang Gemar Menyaru", in Tempo Magazine, Ed. 39/XXXI/25 November-01 December 2002.

“Diakah Sang Imam?”, in Tempo Magazine, Ed. 35/XXXI/28 October-03 November 2002.

"Fakta atau Propaganda Amerika?", in Tempo Magaz̨ine, Ed. 48/XXX/28 January-03 February 2002.

"Gerakan Separatis Belum Usai”, in Tempo Magazine, 18-24 Agust 2003. "Hilangnya Sungkar Dan Ba'asyir", in Tempo Magazine, 16 March 1985. "Indonesia Sarang Teroris", in Tempo Magazine, Ed. 31/XXXI/30 September-06 October 2002. 
"Jaringan Bom Laknat di Malam Kudus", in Tempo Magazine, Ed. 20010//08 - 14 January 2001.

“Jejak Ba'asyir di Sungai Manggis", in Tempo Magąine, Ed. 35/XXXI/28 October-03 November 2002.

"Jenderal Laskar Istimata", in Tempo Magazine, Ed. 33/XXXII/13-19 October 2003.

"Kepenatan itu Terbayar", in http:/ / abbcenter.org/ index.php?option=com_co ntent\&view $=$ article $\& i d=88:$ kepenatan-itu-terbayare catid $=10$ :dariredaksi\& Itemid $=10$ (accessed 8 October 2008)

"Keragu-raguan atas Abu Bakar Ba'asyir", in Tempo Magazine, Ed. 37/ XXXIII/08-14 November 2004.

"Komplotan Baru Pak Guru Dujana", in Tempo Magazine, Ed. 07/ XXXIIIIII/09-15 April 2007.

“Kongres MMI Tanpa Ba'asyir", in Suara Merderka, 10 August 2008.

"Lagi-Lagi Hambali”, in Tempo Magazine, Ed. 35/XXXI/28 October-03 November 2002.

“Lee Menuding, Jakarta Meradang”, in Tempo Magazine, Ed. 52/XXX/25 February- 03 March 2002.

“Mister Lee, Mana Buktinya?”, in Tempo Magazine, Ed. 01/XXXI/04-10 March 2002.

"Mozaik Teror Antar-Bangsa", in Tempo Magazine, Ed. 30/XXXI/23-29 September 2002.

"Muhammad Thalib: Syiah, Ahmadiyah dan Komunis", in Gatra Magarine ed. 39/XIV 13 August 2008.

"Pengakuan JI yang Kurang Meyakinkan”, in Tempo Magazine, Ed. 25/ XXXII/18 - 24 August 2003.

"Pimpinan MMI Harapkan Ba'asyir Hadiri Kongres", in Republika, 8 August 2008.

"Presumed Guilty"in Tempo Magazine, Ed. 50/XXX/11 - 17 February 2003.

"Ragam Kisah Ba'asyir dan Jaringan Ngruki", in Tempo Magazine, Ed. 36/ XXXI/04-10 November 2002.

"Rencana Besar Al-Faruq Al-Kuwaity", in Tempo Magazine, Ed. 30/ 
XXXI/23-29 September 2002.

"Satu Ton Bom di Kios Sandal", in Tempo Magazine, Ed. 33/XXXII/13-19

October 2003.

"Sayap Garis Keras itu Bernama Thoifah Muqatilah", in Tempo Magazine, Edisi. 34/XXXIV/17 - 23 Oktober 2005.

"Setapak Jejak Umar Al-Faruq", in Tempo Magazine, Ed. 31/XXXI/30 September-06 October 2002.

"Setapak Jejak Umar Al-Faruq", in Tempo Magazine, Ed. 31/XXXI/30 September - 06 October 2002.

"Sidney Jones: "Hambali Adalah Petinggi Al-Qaidah", in Tempo Magazine, Ed. 35/XXXI/28 October-03 November 2002.

"Stempel JI dari Singapura", in Tempo Magazine, Ed. 36/XXXI/04-10 November 2002.

"Surat Pernyataan Amirul Mujahidin Abu Bakar Ba'asyir", in bttp:// abbcenter.org/index.php?option=com_contenteview =article Eid =66:perny ataan-mundurecatid=22:pernyataan $\&$ Itemid $=59$ (accessed 8 October 2008)

"Surga di Pelupuk Mata", in Tempo Magazine, Ed. 33/XXXII/13-19 October 2003.

“Tamsil Ditangkap, atau Dijebak?”, in Tempo Magaz̨ine, Ed. 03/XXXI/1824 March 2002.

"Ustad Ba'asyir Mengundurkan Diri dari Majelis Mujahidin”, bttp:/ / wmm. eramuslim.com/berita/nas/8805155942-ustad-ba039asyir-mengundurkandiri-majelis-mujabidin.btm (accessed 6 August 2008)

"Ustad Berpisah Jamaah Terbelah", in Gatra Magazine, No. 39 /XIV 13 August 2008.

"Ustadz Abu Bakar Ba'asyir Disuruh Mundur Irfan", at bttp:/ / infojïhad. wordpress.com/2008/08/07/ustadz-abu-bakar-baasyir-disurub-mundurirfan/ (accessed 10 August 2008)

"Abu Bakar Ba'asyir at the center of controversy" at http://www. thejakartapost.com/news/2003/03/08/abu-bakar-ba039asyir-centercontroversy.html (accessed 1 November 2008)

Al-Jamaah al-Islamiyyah, The General Guide for the Struggle of Jamaah 
Islamiyyah (Pedoman Umum Perjuangan Jamaah islamiyyah/PUPJI), 30 May 1996.

Ba'asyir Speech in his 1982 court (10 March 1982)

Bruinessen, Martin van, Genealogies of Islamic Radicalism in postSuharto Indonesia" in http:// wmm.let.uu.nl/ Martin.vanBruinessen/ personal/publications/genealogies_islamic_radicalism.btm (accessed, 17 July 2008)

Court's exceptions with the title "Idiologi Negara Pancasila, Gerakan Komunisme dan Ajaran Islam" (Ideology of Pancasila State, Communist Movement and Islam), of Both Sungkar and Ba'asyir in 1982.

Irfan S. Awwas, "Menegakkan Syariat tanpa Teror", in Tempo Magazine, Ed. 38/XXXI/18-24 November 2002.

Leirissa, R.Z., "PRRI: Membangun Indonesia Tanpa Komunis", in Tempo Magazine, Ed. 21/XXXVII/14 - 20 July 2008.

Liddle, R. William, “al-Faruq dan Indonesia”, in Tempo Magażine, Ed. 33/ XXXI/14 - 20 October 2002.

Majelis Mujahidin Indonesia, Official Opinion on International Terrorism, issued on 10 March 2002.

PPME, The Muslim Youth Association of Europe's report, presented in the Indonesian Embassy in the Netherlands on 25-26 August 1973.

Sungkar's Speech in his 1982 court (10 March 1982).

Thalib Muhammad, "Syiah Ahmadiyah dan Komunis", in Gatra Magazine, 39/XIV 13 August 2008.

The Court Report of Sungkar's and Ba'asyir's Trial in 1982. 